\title{
Survival of shigellae in food*
}

\author{
By BARBARA C. TAYLOR AND MITSURU NAKAMURA \\ Department of Microbiology, Montana State University, \\ Missoula, Montana, U.S.A.
}

(Received 27 January 1964)

\section{INTRODUCTION}

Various food preparations may harbour and transmit Shigella to humans, which may result in clinical bacillary dysentery. The longevity of shigellae in food materials is therefore of fundamental importance in the epidemiology of shigellosis. Some data are available on the survival of Shigella species in a variety of environments (Wilson \& Tanner, 1945; Hartsell, 1951 $a$; Shrewsbury \& Barson, 1957; Talayeva, 1960; Nakamura, 1962). In the present investigation we determined the survival of S. flexneri and S. sonnei in various foods and food products, namely milk, orange juice, whole egg, egg white, oyster, clam, shrimp, flour, tomato juice, root beer and cooking oil. Furthermore, the survival and persistence of the shigellae in these food preparations were studied at several temperatures.

\section{MATERIALS AND METHODS}

Cultures employed in these experiments were maintained on nutrient agar, stored at $0.5^{\circ} \mathrm{C}$., transferred every 4 weeks, and tested serologically for purity with Bacto-Shigella Antisera (Difco). S. flexneri serotype 2 a was supplied by Dr W. H. Ewing, Laboratory Branch, Communicable Disease Center, Atlanta, Georgia; S. sonnei strain 13327 was obtained from Frank P. Pauls, South Central Regional Laboratory, Department of Health and Welfare, Anchorage, Alaska; strain B-2569-2 of S. sonnei was sent to us by Commander T. M. Floyd, U.S. Naval Medical Center, Bethesda, Maryland.

Cells for survival studies were harvested from the third consecutive transfer of actively growing cultures. Inocula were prepared from each of the cultures used by washing $24 \mathrm{hr}$. nutrient broth cultures in sterile physiological saline and resuspending the cells in saline. Suspensions of cells consisting of 1.5 to $3.5 \times 10^{8}$ cells/ $\mathrm{ml}$. were added in $1 \mathrm{ml}$. volumes to tubes containing various sterile menstrua. These suspensions were standardized by measurement of optical density, and plate counts were made at the time the menstrua were inoculated for determination of the initial cell concentration. We have taken the liberty of using the term menstruum to designate the food preparation in which survival of shigellae was determined. We are aware of the fact that this is a demarcation from the definition of the term, namely, a solvent. Each menstruum was tubed and sterilized; in some

* This investigation was supported in part by a research grant from the National Institute of Allergy and Infectious Diseases (E-3734-C2), U.S.P.H.S. 
cases the food preparation was dispensed aseptically into sterile containers and survival studies performed without sterilization of the menstruum.

\section{Preparation of menstrua}

Milk. Pasteurized, homogenized whole milk containing vitamin $\mathrm{D}$ was obtained from a commercial source, dispensed in screw-capped test tubes $(16 \times 150 \mathrm{~mm}$. $)$ in $9 \cdot 0 \mathrm{ml}$. amounts, and autoclaved.

Orange juice. Frozen concentrated orange juice (Old South) was reconstituted. The $\mathrm{pH}$ of the juice was 3.7 ; the juice was tubed in $9.0 \mathrm{ml}$. amounts and autoclaved. In a second series of experiments the orange juice was adjusted to $\mathrm{pH} \mathrm{7.0}$ with $\mathrm{NaOH}$.

Whole egg. One-day-old eggs were obtained from a farm, soaked in $60 \%$ ethyl alcohol for $5 \mathrm{~min}$., allowed to drain dry on sterile gauze pads, broken open aseptically in an ultra-violet light chamber and blended in a Waring Blendor for about 3 sec. Samples of the blended egg were dispensed into sterile test tubes, sterility tests being put up at the same time.

Egg white. This was prepared similarly to the whole egg except that the white was separated aseptically from the yolk of each egg before blending.

Oyster, clam and shrimp. Commercially canned sea foods were packaged in metal-capped tubes and autoclaved. Whole oysters (Finer Foods) with salt added were cut into pieces weighing approximately $1 \mathrm{~g}$. each. Minced sea clams (Sonny Boy) with salt and monosodium glutamate added were tubed in approximately 1 g. amounts. Whole small shrimps (Blue Plate Shor-Pak) with salt added were found to weigh approximately $1 \mathrm{~g}$. each and were tubed individually.

Carbonated beverages. Root beer (Hires) and ginger ale (Clicquot Club) were inoculated with organisms directly into their commercial glass containers. In preparation, the bottles were washed with soap and water and opened with a bottle opener which had been flamed.

\section{Sampling procedures}

At various intervals the food products containing the shigellae were sampled. Liquid preparations were decimally diluted and plate-counted. Dilutions of $10^{-3}, 10^{-5}$, and $10^{-7}$ were simultaneously plated in duplicate. Towards the end of the survival period when the population declined considerably, $0.1 \mathrm{ml}$. of the undiluted menstruum was also plated.

Whole objects including oysters, clams, etc., were blended in sterile Waring Blendor cups for 3 sec. and the suspension decimally diluted for the plate counts.

At least ten samples were studied in duplicate for each food preparation at each holding temperature. Standard plate count techniques were used to determine the number of viable cells. Surviving fraction curves were determined by dividing the number of cells surviving by the number in the initial population. 


\section{RESULTS}

The survival periods of the shigellae in various food preparations at different temperatures are illustrated in Figs. 1 and 2. In general, the survival rates of $S$. sonnei and $S$. flexneri in various menstrua were comparable. However, there

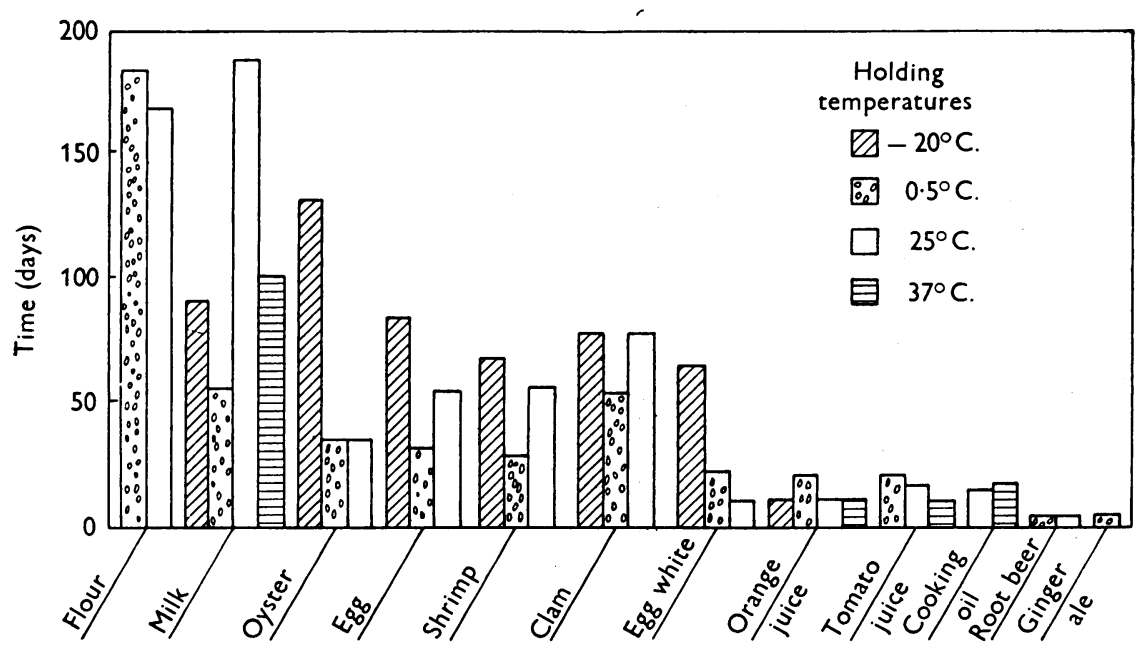

Fig. 1. Survival of Shigella flexneri in foods.

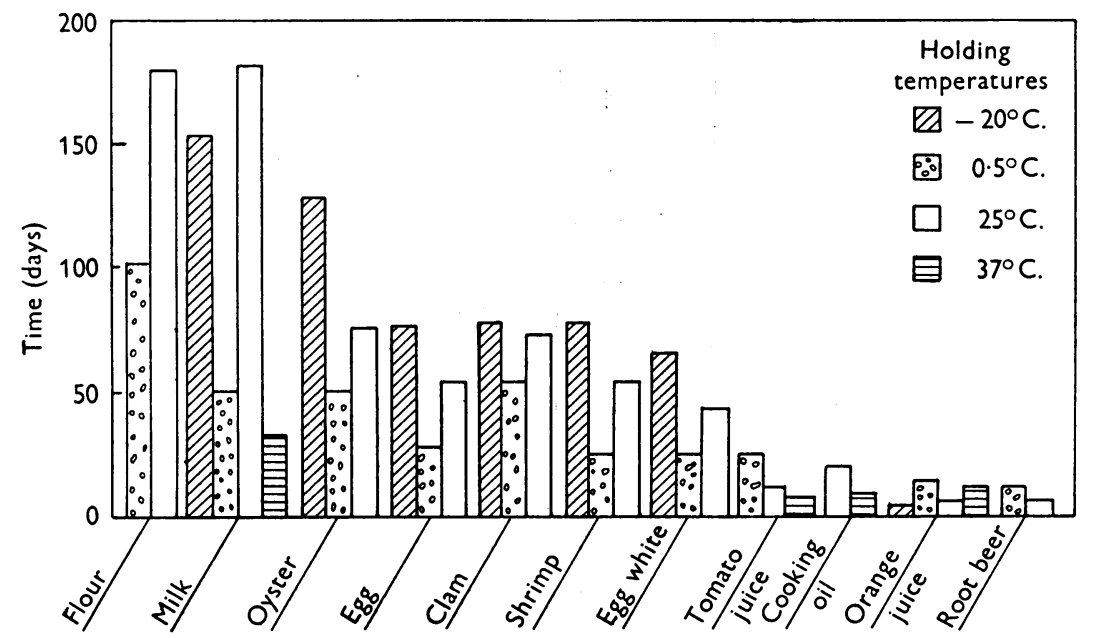

Fig. 2. Survival of Shigella sonnei B-2569-2 in foods.

was a considerable difference in the survival rates at the different holding temperatures. The survival periods were longest when the holding temperature was $25^{\circ} \mathrm{C}$. or lower. The length of time the shigellae survived varied also with the menstrua. For example, the organisms survived for over 170 days in flour and milk and for lesser periods in oyster, egg, shrimp, clam, and egg white, and for relatively short periods in orange juice, tomato juice, cooking oil, root beer, and ginger ale. Factors which may have influenced these differences will be discussed later. 
The survival of Shigella in milk at different temperatures is illustrated in Fig. 3. The surviving fractions decreased slowly and persisted for long periods; in fact, in some cases the numbers increased, possibly owing to multiplication of the organisms
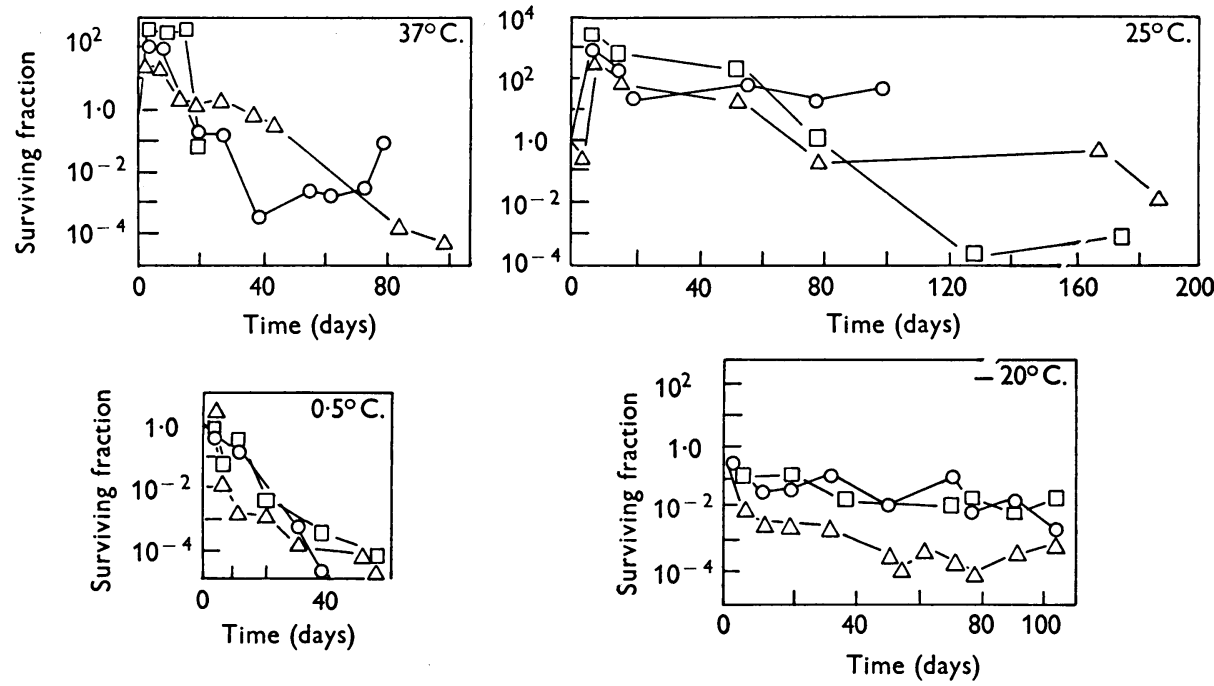

Fig. 3. Survival of Shigella spp. in milk: $-\Delta-\Delta-$ S. flexneri; $-\mathrm{O}-\mathrm{O}-$ S. sonnei 13327 ; - $\square-\square-S$. sonnei B-2569-2.
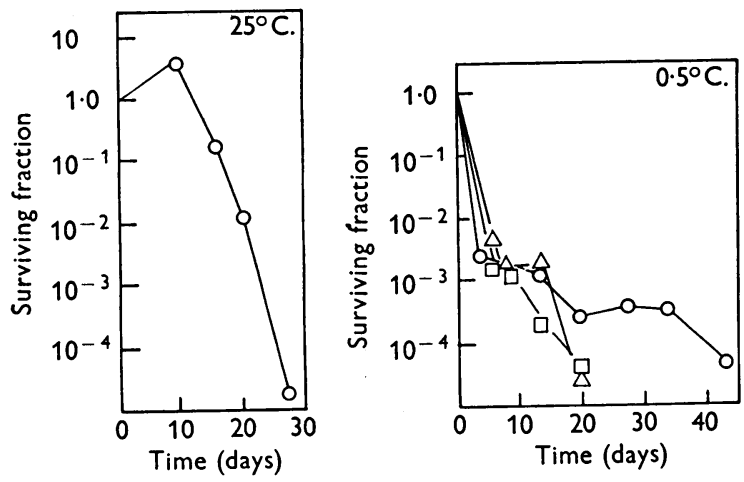

Tomato juice
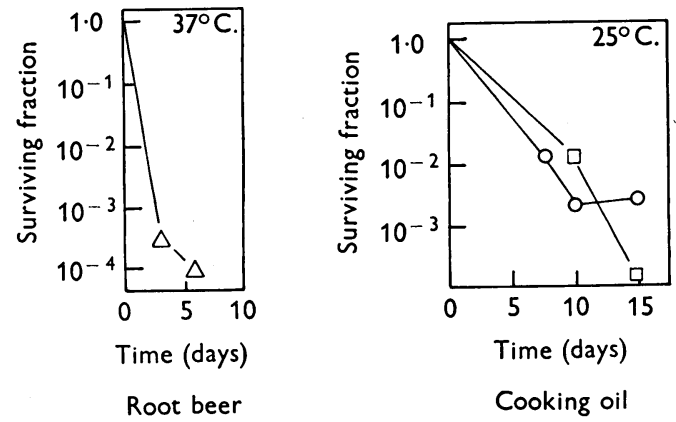

Fig. 4. Survival of Shigella spp. in tomato juice, root beer and oil: $-\triangle-\triangle-S$. flexneri; -O-O-S. sonnei 13327; - $\square-\square-S$. sonnei B-2569-2. 

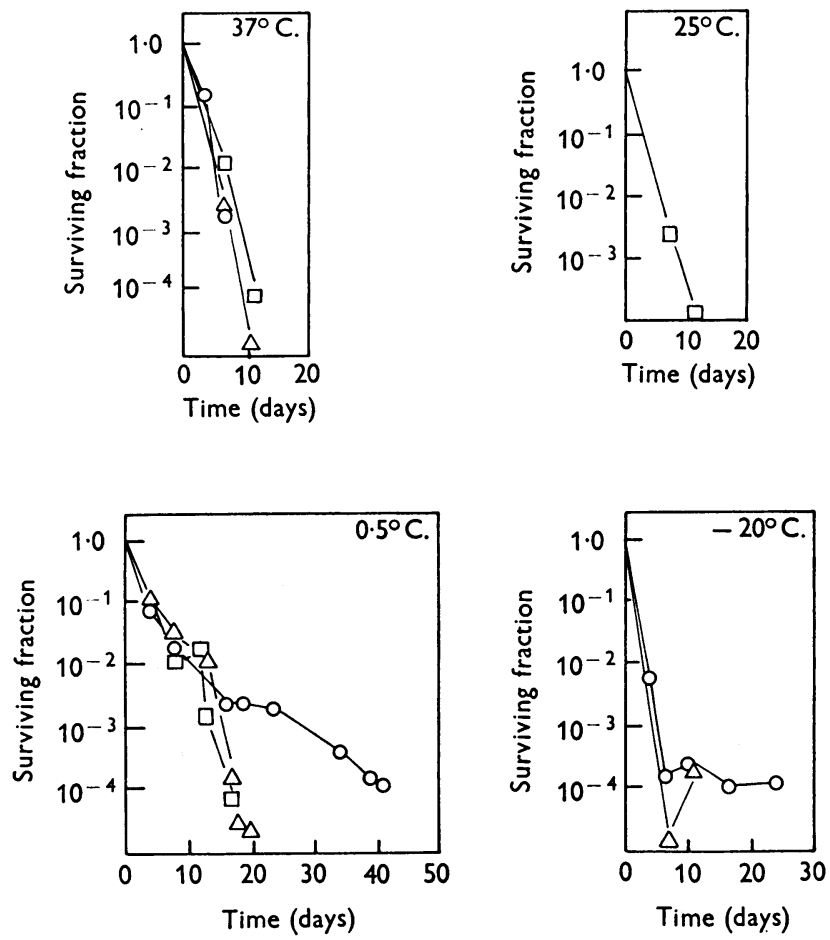

Fig. 5. Survival of Shigella spp. in orange juice: $-\triangle-\triangle-S$. flexneri; $-\mathrm{O}-\mathrm{O}-\mathrm{S}$. sonnei 13327 ; $-\square-\square-S$. sonnei B-2569-2.
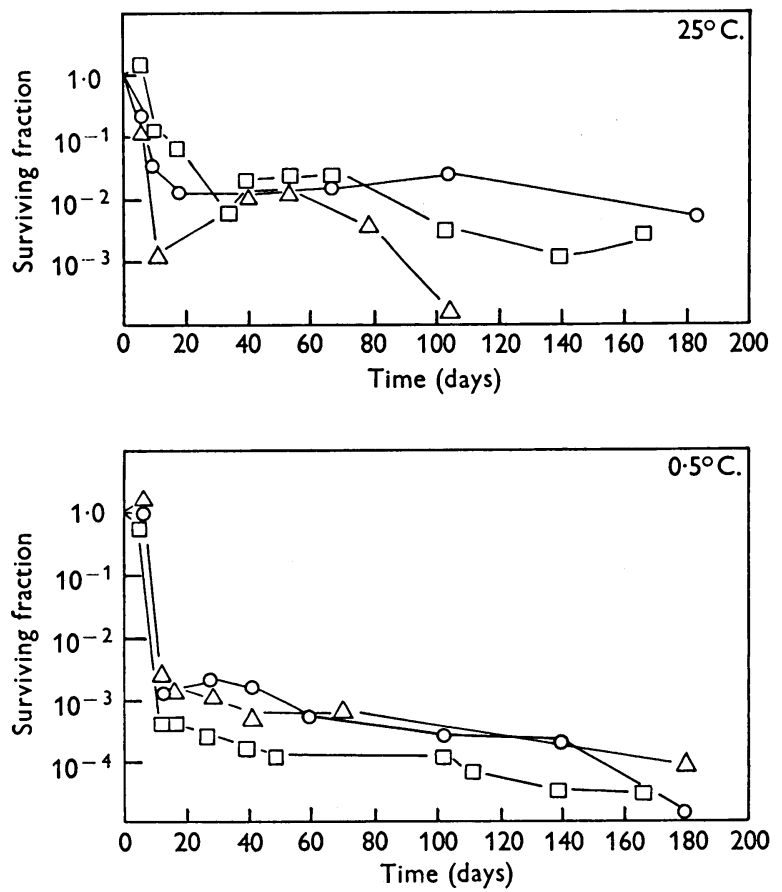

Fig. 6. Survival of Shigella spp. in flour: $-\triangle-\triangle-S$. flexneri; $-O-O-S$. sonnei 13327; $-\square-\square-S$. sonnei B-2569-2. 
in the milk at the higher temperatures. By contrast, the surviving fractions declined rapidly when the shigellae were placed in tomato juice, root beer, cooking oil, and orange juice (see Figs. 4 and 5).

The longevity and persistence of shigellae in flour, egg white, oyster, clams, shrimp, and whole egg are illustrated in Figs. 6-11.
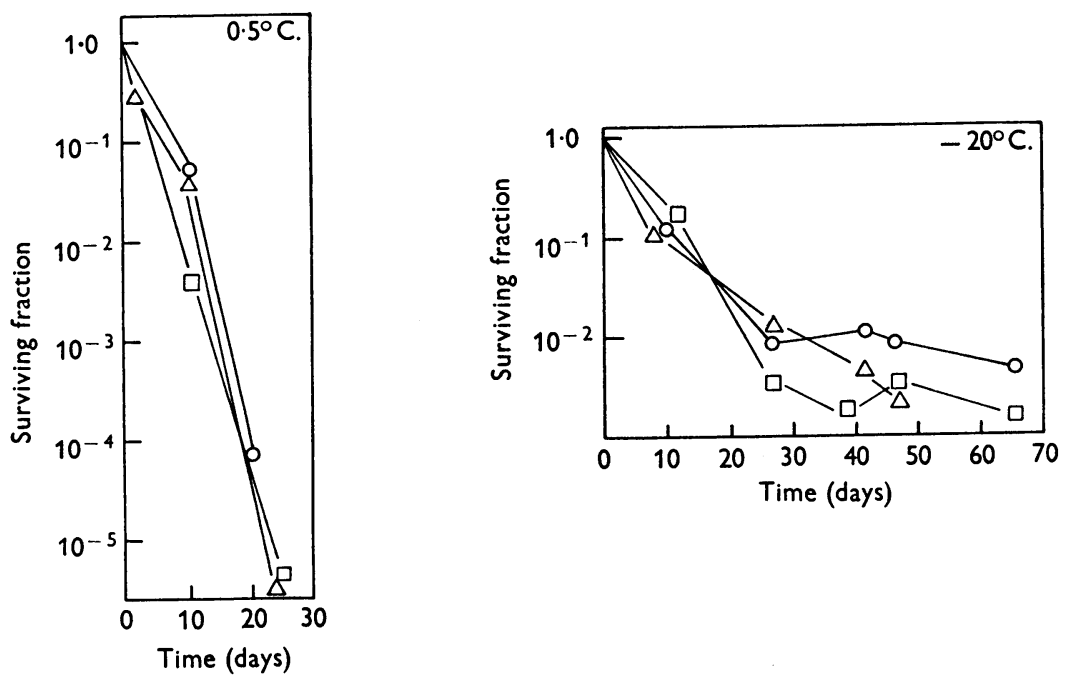

Fig. 7. Survival of Shigella spp. in egg white: $-\Delta-\Delta-S$. flexneri; $-0-0-S$. sonnei 13327; - $\square-\square-S$. sonnei B-2569-2.
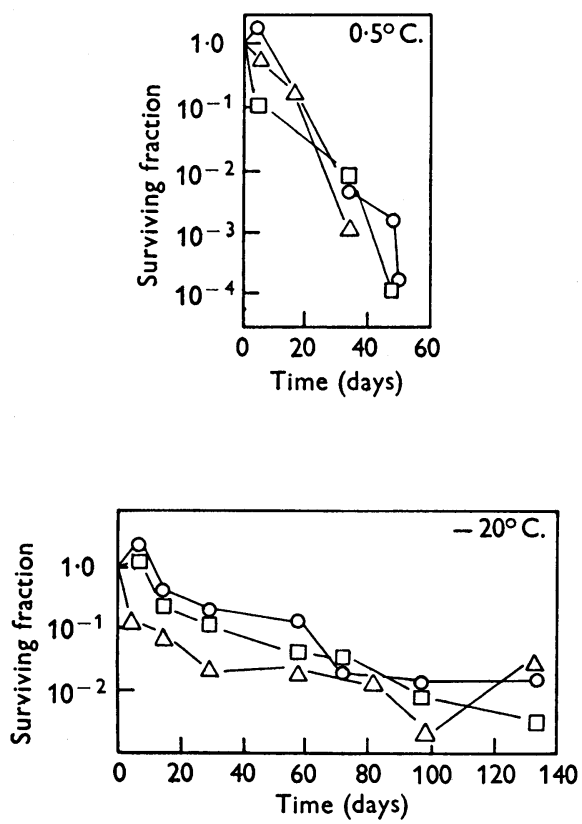

Fig. 8. Survival of Shigella spp. in oyster: $-\Delta-\Delta-S$. flexneri; $-0-0-S$. sonnei 13327; 


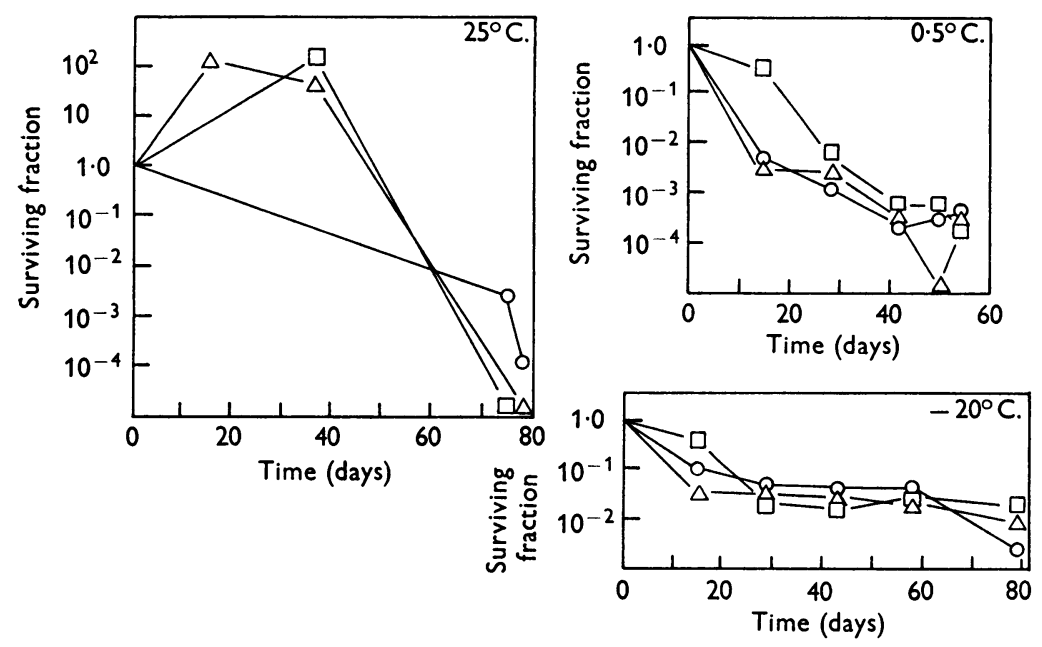

Fig. 9. Survival of Shigella spp. in clams: $-\Delta-\Delta-$ S. flexneri; $-0-0-S$. sonnei 13327; - $\square-\square-S$. sonnei B-2569-2.
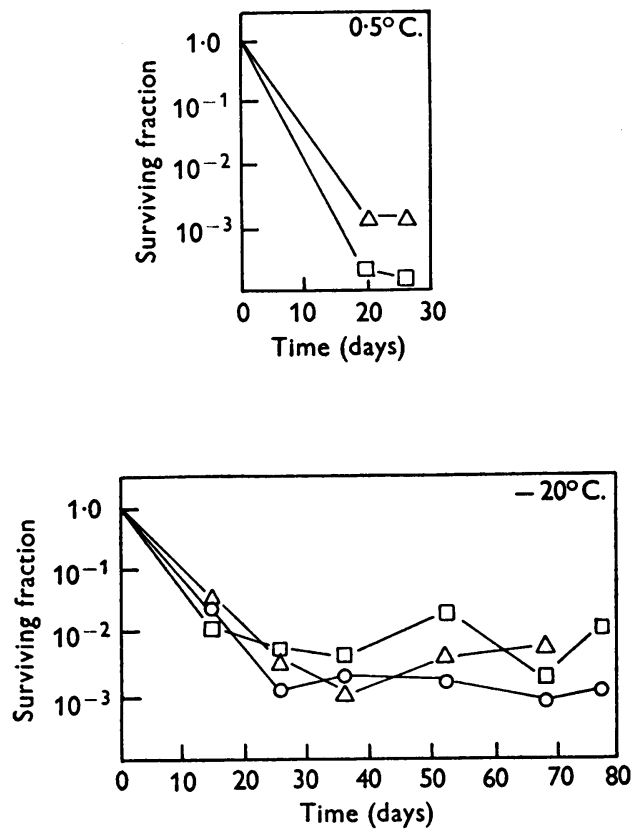

Fig. 10. Survival of Shigella spp. in shrimp: $-\Delta-\Delta-S$. flexneri; $-0-0-S$. sonnei 13327; - $\square-\square-S$. sonnei B-2569-2.

\section{DISCUSSION}

The recovery of shigellae from the various menstrua is an indication of biologically undamaged and viable cells. Although the recovery medium used was a complex medium it is conceivable that some viable cells were not recovered. Hartsell $(1951 a, b)$ and Nakamura \& Dawson (1962) reported that highly nutritive media were necessary to recover Shigella species from the frozen state. In our 
experiments it appeared that some menstrua propagated the organism, whereas others protected the cells from damage (extended survival in certain substances). In addition, it appeared that some menstrua were toxic to shigellae as noted by the sharp drop in the surviving fractions. Since Naylor \& Smith (1946), Meynell (1958), and Mead, Wessman, Higuchi \& Surgalla (1960) found that the survival of micro-organisms was optimal in cultures during the early stationary growth phase, it is very probable that the organisms used in these experiments possessed the capabilities of maximal survival.
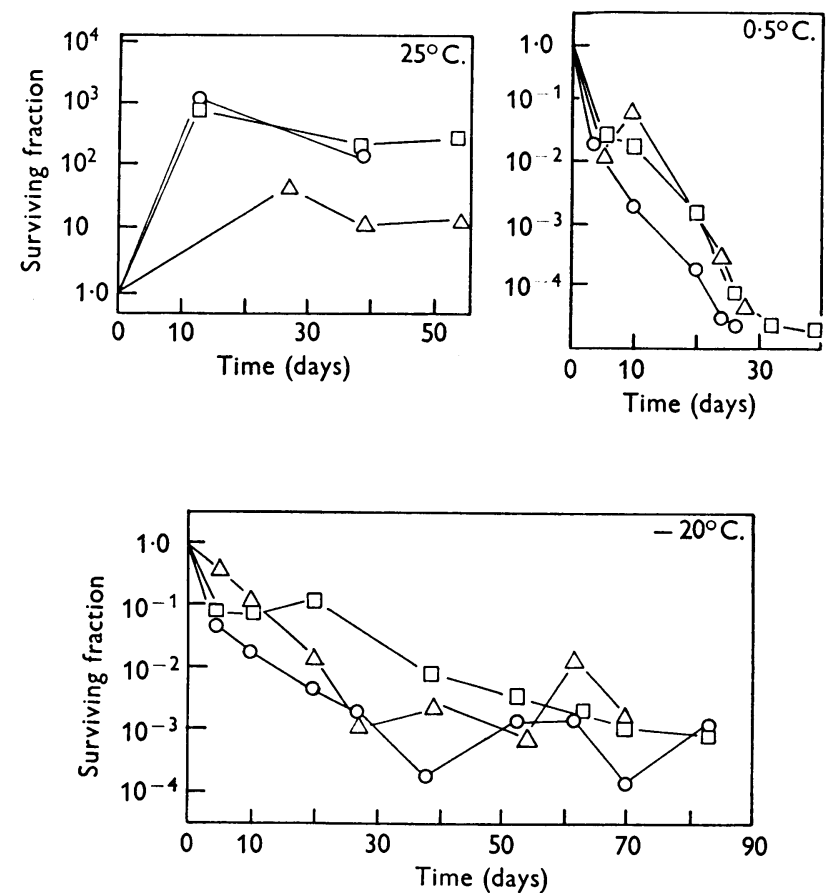

Fig. 11. Survival of Shigella spp. in whole egg: $-\triangle-\triangle-S$. flexneri; -O-O-S. sonnei 13327; - $\square-\square-S$. sonnei B-2569-2.

The survival curves of Shigella in milk, flour, oyster, clams, shrimp and whole egg showed an initial steep decline which was followed by decreased slopes as time increased and later the slopes became almost negligible. This pattern is in agreement with the results obtained by others (Hartsell, 1951b; Major, McDougal \& Harrison, 1955; Clement, 1961).

The shigellae did not survive very long in orange juice. Orange juice is acidic and contains citric acid which was reported to be lethal to some bacteria (Erickson \& Fabian, 1942; Hahn \& Appleman, 1952a, $b$ ). When we neutralized the orange juice before the addition of the inocula the survival was double that in the unneutralized orange juice. The total survival period was not very extensive, however. The limited survival of the organisms in tomato juice was probably also due to the low $\mathrm{pH}(4 \cdot 5)$ of the juice. Johnston \& Kaake (1935) found that S. dysenteriae cells could not be recovered from tomatoes after 6 days. 
The shigellae survived for only brief periods in the carbonated beverages studied. Low $\mathrm{pH}$ was probably also a factor in limiting survival (Ramadan \& Abd-Elnaby, 1962). Eagon \& Green (1957) concluded that carbonation increased the bactericidal activity of acid environments. Cooking oil provided poor conditions for the survival of shigellae; this was in agreement with the work of Pivnick, Englehard \& Thompson (1954), who reported on the limited survival of enteric pathogens in soluble oil emulsions at $20^{\circ} \mathrm{C}$.

\section{SUMMARY}

The survival and persistence of Shigella sonnei and S. flexneri in various food preparations were studied. The length of survival and the rate of decrease in surviving fractions varied considerably depending upon the menstruum and the holding temperature. This study points out the potential hazards involved in consuming food products that may be contaminated by shigellae.

\section{REFERENCES}

Clement, M. T. (1961). Effects of freezing, freeze-drying, and storage in the freeze-dried and frozen state on viability of Escherichia coli. Canad. J. Microbiol. 7, 99.

EAGON, R. G. \& GREEN, C. R. (1957). Effect of carbonated beverages on bacteria. Food Res. $22,687$.

Erickson, F. J. \& Fabian, F. W. (1942). Preserving and germicidal action of various sugars and organic acids on yeasts and bacteria. Food Res. 7, 68.

Hahn, S. S. \& Appleman, M. D. (1952a). Microbiology of frozen orange concentrate. I. Survival of enteric organisms in frozen orange concentrate. Food Tech. 6, 156.

Hahn, S. S. \& Appleman, M. D. (1952b). Microbiology of frozen orange concentrate. II. Factors influencing survival of microorganisms in frozen orange concentrate. Food Tech. $6,165$.

HARTSELL, S. E. (195l $a$ ). The longevity and behavior of pathogenic bacteria in frozen foods: the influence of plating media. Amer. J. publ. Hlth, 41, 1072.

HartSell, S. E. (1951 b). The growth initiation of bacteria in defrosted eggs. Food Res. 16, 97.

Johnston, M. N. \& KaAke, M. J. (1935). Bacteria on fresh fruit. Amer. J. publ. Hlth, 25, 945.

Major, C. P., McDougal, J. D. \& Harrison, A. P., Jr. (1955). The effect of the initial cell concentration upon survival of bacteria at -22 C. J. Bact. 69, 244.

Mead, D. D., Wessman, G. E., Higuchi, K. \& Surgalla, M. J. (1960). Stability of cell suspensions of Pasteurella pestis at 5 C. and -23 C. Appl. Microbiol. 8, 55.

Meynell, G. G. (1958). The effect of sudden chilling on Escherichia coli. J. gen. Microbiol. 19,380 .

Nakamura, M. (1962). The survival of Shigella sonnei on cotton, glass, wood, paper, and metal at various temperatures. J. Hyg., Camb., 60, 35.

Nakamura, M. \& Dawson, D. A. (1962). Role of suspending and recovery media in the survival of frozen Shigella sonnei. Appl. Microbiol. 10, 40.

NaYlor, H. B. \& Smith, P. A. (1946). Factors affecting the viability of Serratia marcescens during dehydration and storage. J. Bact. 52, 565.

Pivnick, H., Engelhard, W. E. \& Thompson, T. L. (1954). The growth of pathogenic bacteria in soluble oil emulsions. Appl. Microbiol. 2, 6.

Ramadan, F. M. \& ABD-Elnaby, H. A. (1962). Bacteriological examination of unbottled soft drinks. Appl. Microbiol. 10, 311.

Shrewsbury, J. F. D. \& Barson, G. J. (1957). On the absolute viability of certain pathogenic bacteria in a synthetic well-water. J. Path. Bact. 74, 215.

TALAYEVA, J. G. (1960). Survival of dysentery bacteria in water according to the results of a reaction with haptenes. J. Hyg. Epidem. (Praha), 4, 314.

Wilson, F. L. \& TANNER, F. W. (1945). Behavior of pathogenic bacteria in fermented milks. Food Res. 10, 122. 